\title{
KONSISTENSI HUKUM WORLD TRADE ORGANIZATION (WTO) MENGENAI PRINSIP MOST FAVORED NATION (MFN) ATAS REGIONALISME DAN PANDANGANNYA TERHADAP ASEAN ECONOMIC COMMUNITY (AEC)
}

\author{
Marko Cahya Sutanto \\ email: marko.sutanto@gmail.com
}

\begin{abstract}
In 2015, Indonesia and other ASEAN members have a commitment to establish a single market region, i.e. free flow of goods and service, termed ASEAN Economic Community (hereinafter 'AEC'). This arrangement is contrary to Most Favored Nation (MFN) principle under the General Agreement on Tariffs and Trade 1994, (hereinafter 'GATT'). This paper aims to address the said violation according to the WTO/GATT law by analyzing (1) the general obligations and exceptions under the WTO/GATT, (2) regionalism in general and its existence in Southeast Asia, and (3) the interpretation of WTO's compromise to regionalism. Under the GATT, there is a general obligation for members to treat their trading partners equally and give the same benefits to other members. However, there is an exception to this principle under article XXIV of the GATT, which based on the notion that regional trade agreements are a building block for multilateral openness. Yet, before applying this exception to the case at hand, $A E C^{\prime}$ 's form must be determined. AEC' has a structure of Free-Trade Area (hereinafter 'FTA') with a single market adhere to it, which according to WTO's database there is one in force at the moment, namely ASEAN Free Trade Area (hereinafter 'AFTA'). AFTA is not the equivalent to AEC because it covers more than just goods. Thus, the answer to apply the exception to $A E C$ is inconclusive because even though it fits normatively, it does not have the necessary legitimacy.
\end{abstract}

Keywords:

ASEAN Economic Community (AEC), Most Favored Nation (MFN) Principle, Regionalism, General Agreement on Tariffs and Trade (GATT)

\begin{abstract}
Abstrak
Di tahun 2015, Indonesia dan anggota ASEAN lainnya memiliki komitmen untuk membentuk kawasan satu pasar, yakni arus bebas barang dan jasa, ditermakan dengan ASEAN Economic Community (AEC). Pengaturan ini akan bertentangan dengan prinsip Most Favored Nation (MFN) yang tertuang di dalam General Agreement on Tarrifs and Trade 1994 (GATT). Penulisan ini bertujuan untuk menjawab pertanyaan pelanggaran tersebut berdasarkan hukum WTO/GATT dengan menganalisis (1) kewajiban-kewajiban umum dan pengecualiannya di bawah WTO/GATT, (2) regionalisme secara umum dan keberadaannya di Asia Tenggara, dan (3) interpretasi kompromi WTO atas regionalisme. Di bawah GATT, terdapat kewajiban umum bagi partisipan untuk memperlakukan mitra dagangnya secara adil dan memberikan keuntungan yang sama kepada anggota lainnya. Namun, terdapat pengecualian atas prinsip tersebut berdasarkan article XXIV dari GATT, yang mana pengecualian ini berdasarkan pada gagasan bahwa perjanjian dagang regional sebagai batu pijakan atas keterbukaan multilateral. Tetapi, sebelum menerapkan eksepsi tersebut, bentuk AEC harus ditentukan terlebih dahulu. AEC memiliki bentuk Free-Trade Area (FTA) dengan single market yang melekat padanya, berdasarkan database WTO yang berlaku saat ini yaitu ASEAN Free Trade Area (AFTA). AFTA tidak sama dengan dengan AEC karena mencakup
\end{abstract}


lebih daripada sekedar barang. Sehingga, jawaban atas eksepsi ini menjadi tidak jelas karena meskipun dapat terpenuhi secara normatif, ia tidak mendapatkan legitimasi yang diperlukan.

Kata Kunci:

ASEAN Economic Community (AEC)/Masyarakat Ekonomi ASEAN (MEA), Most Favored Nation (MFN), Regionalisme, Komitmen dan Kompromi Hukum, General Agreement on Tariffs and Trade

(GATT)

\section{Pendahuluan}

Indonesia bersama-sama dengan negara-negara Association Of Southeast Asian Nations (ASEAN) yang lainnya pada tahun 2015 akan membentuk ASEAN Economic Community (AEC)/Masyarakat Ekonomi ASEAN (MEA) ${ }^{1}$. Komitmen untuk membentuk satu pasar di kawasan Asia Tenggara tersebut, tertuang di dalam satu wadah yaitu AEC, diwujudkan dengan pengadopsian AEC Blueprint/Cetakbiru MEA pada tanggal 20 November 2007 di Singapura². Tujuan pembentukan kawasan satu pasar (single market) dan basis produksi (production base) tersebut adalah demi terwujudnya wilayah yang kompetitif dan terintegrasi dengan pasar global ${ }^{3}$.

Komitmen atas manifestasi kawasan integrasi ekonomi ini akan bertentangan dengan komitmen-komitmen lainnya yang dideklarasikan sebelumnya terutama atas komitmen dengan World Trade Organization (WTO) yang tertuang dalam General Agreement on Tariffs and Trade (GATT) ${ }^{4}$. Seluruh

\footnotetext{
1 ASEAN dibentuk pada tanggal 8 Agustus 1967 dan hingga saat ini terdiri atas 10 negara anggota yakni Brunei Darussalam, Kamboja, Indonesia, Laos, Malaysia, Myanmar, Filipina, Singapura, Thailand, dan Vietnam (tersedia di http://www.asean.org/asean/asean-member-states, terakhir diakses 4 April , 2015).

2 Lihat,, AEC Blueprint, declaration, tersedia di http://www.asean.org/archive/5187-10.pdf (terakhir diakses 4 April, 2015). See also generally, Thu, infra catatan no. 28, pada 6-8 (Sejarah hingga ke AEC). Secara sederhana dimulai dari ASEAN Free Trade Area (AFTA) pada tahun 1992 dengan ditandatangani skema Common Effective Preferential Tariff (CEPT) untuk mengurangi tarif hingga pada taraf $0-5 \%$ atas perdagangan intra-regional. Dilanjutkan dengan ASEAN Investment Area (AIA) pada tahun 1988 dengan target untuk membuat Asia Tenggara menjadi kawasan yang atraktif bagi investor ASEAN maupun non-ASEAN.

${ }^{3}$ Lihat., Id., point 6.

4 WTO merupakan organisasi perdagangan internasional yang mengandung perjanjian-perjanjian multilateral yang masif. Hingga saat ini WTO beranggotakan 160 negara sejak 26 Juni 2014 tersedia di https://www.wto.org/english/thewto_e/whatis_e/tif_e/org6_e.htm (terakhir diakses pada 15 April, 2015). See., also, WTO, Member Information: Indonesia and the WTO,
} 
negara anggota ASEAN merupakan negara partisipan dalam WTO, yang terikat pada prinsip yang melarang diskriminasi terhadap mitra dagangnya, dinamakan juga prinsip Most Favored Nation (MFN) ${ }^{5}$. Namun, melihat konsep AEC yang merujuk arus bebas barang, struktur perdagangan internasional ini sifatnya internal (terikat pada region/kawasan) dan akan dikenakan tarif yang hampir 0\% serta pencabutan atas penghalang yang bukan merupakan tarif6. Sehingga strukturisasi tersebut tentu akan menimbulkan diskriminasi bagi negara ketiga/negara non-anggota.

Pengaturan seperti ini ditermakan dengan regionalisme (regionalism) dimana beberapa negara bersatu membentuk bloknya sendiri demi memajukan arealnya dengan cara liberalisasi perdagangan atas barang, jasa, investasi, dan kapital7. Akibatnya, non-negara partisipan tidak dapat menikmati perlakuan tersebut di atas. Di sinilah fokus penelitian ini, yaitu mempersoalkan konsistensi hukum WTO mengenai prinsip MFN dan sejauh mana kompromi WTO atas regionalisme. Sistematika dalam penelitian akan membahas mengenai (1) Kewajiban umum di bawah WTO, (2) Regionalisme, dan (3) Interpretasi kompromi WTO atas pembentukan AEC.

\section{Prinsip-Prinsip Fundamental dan Pengecualian dalam WT0/GATT: General Obligations (Kewajiban-Kewajiban Umum) di Bawah WTO/GATT}

\section{MFN dan National Treatment.}

Prinsip Most Favored Nation (MFN) dan National Treatment merupakan dua prinsip fundamental yang terkandung di dalam General Agreement On Tariffs And Trade (GATT) dan berlaku pada setiap negara anggotanya yang notabene

https://www.wto.org/english/thewto_e/countries_e/indonesia_e.htm (terakhir diakses 8 July, 2015) (Indonesia menjadi anggota WTO sejak 1 Januari, 1995).

${ }^{5}$ Lihat, WTO, Understanding the WTO: Basics - Principles Of The Trading System, World Trade Organization, tersedia di https://www.wto.org/english/thewto_e/whatis_e/tif_e/fact2_e.htm (terakhir diakses 5 April, 2015).

${ }^{6}$ Lihat, AEC Blueprint point 10.

${ }^{7}$ Lihat, Id., point. 5 and 9. Hal-hal yang disebutkan merupakan 5 elemen penting dalam AEC. 
seluruh negara partisipan dalam WTO $^{8}$. Selain terdapat di dalam GATT, prinsip tersebut terkandung juga di dalam perjanjian-perjanjian yang lain seperti General Agreement On Trade In Service (GATS) dan Trade-Related Aspects Of Intellectual Property Rights (TRIPS). Namun, dalam perjanjian-perjanjian tersebut terdapat sedikit perbedaan meskipun secara esensi atau jiwa sama. Secara sederhana article I dari GATT menyebutkan prinsip MFN yaitu members are bound to provide the products of each member tariff treatment no less favorable than that accorded the products of any member ${ }^{9}$. Selanjutnya, article III dari GATT menyatakan prinsip National Treatment yaitu once imports have entered a market, they be treated no less favorably than equivalent domestically produced goods ${ }^{10}$. Sehingga, dapat disimpulkan bahwa kedua prinsip tersebut menghendaki agar negara-negara partisipan dalam WTO tidak mendiskriminasikan sesamanya (prinsip nondiskriminasi/non-discrimination), serta prinsip MFN merupakan tindakan di perbatasan sedangkan National Treatment berlaku internal setelah produk tersebut masuk ke dalam pasar.

Setelah mengetahui secara sederhana mengenai general obligation sebagai negara anggota GATT/WTO, diperlukan analisis mendalam mengenai salah satu prinsip-prinsip tersebut yaitu Most Favored Nation (MFN). Menjadi negara partisipan dalam WTO berarti terikat atas seluruh peraturan-peraturan yang terkandung di dalamnya, hal ini ditermakan dengan 'single undertaking'. Single

\footnotetext{
${ }^{8}$ Teks GATT yang original adalah GATT tahun 1947 dan telah dimodifikasi di oleh GATT 1994. See also., Trost, infra catatan no.68, 195 (Mengenai sejarah GATT secara singkat).

${ }^{9}$ Lihat, Anonymous, WTO Basics, The China Bus. Rev., 36 (2000). See also., WTO, Understanding The WTO: Basics-Principle Of Trading System, tersedia di https://www.wto.org/english/ thewto_e/whatis_e/tif_e/fact2_e.htm (terakhir diakses 10 April, 2015). Untuk mempermudah pengertian prinsip ini, di bawah perjanjian-perjanjian WTO, negara-negara tidak dapat mendiskriminasikan mitra dagangnya. Bila diberikan perlakuan khusus seperti penurunan bea masuk kepada satu negara, maka negara pengimpor harus memberikan perlakuan sama terhadap negara anggota WTO yang lainnya.

${ }^{10}$ Lihat, Id. Lihat juga, WTO, Understanding The WTO: Basics - Principle Of Trading System, Tersedia di https://www.wto.org/english/thewto_e/whatis_e/tif_e/fact2_e.htm (terakhir diakses 10 April, 2015). Dalam hal ini WTO menghendaki bahwa produk-produk impor maupun lokal diperlakukan sederajat tanpa diskriminasi setelah produk tersebut masuk ke dalam pasar. Mengingat bahwa prinsip ini berlaku setelah produk masuk ke dalam pasar sehingga pemberian bea masuk tidak melanggar prinsip ini meskipun produk lokal tidak diberikan sejumlah pajak yang sama dengan bea masuk.
} 
undertaking ini mengikat seluruh negara anggota WTO sebagai hasil dari negosiasi Uruguay Round yang mengukuhkan prinsip fundamental yaitu MFN dan juga Doha Declaration dimana para negara anggota menyatakan komitmennya atas WTO sebagai forum istimewa pembuat peraturan yang global dan basis promosi atas liberalisasi perdagangan ${ }^{11}$. Melihat kedua round ini, tampak bahwa agenda WTO adalah globalisasi dengan cara mengikat anggota-anggotanya dengan komitmenkomitmen yang tertuang di dalam perjanjian-perjanijan multilateral. Di dalam Doha Round ini juga terdapat hal yang krusial yaitu WTO mengakui bahwa perjanjian-perjanjian dagang regional memiliki peran penting dalam mempromosikan liberalisasi dan ekspansi dagang ${ }^{12}$. Terlihatlah inkonsistensi dalam kedua round yang telah disebutkan sebelumnya yaitu mengukuhkan prinsip MFN dan kemudian mengakui perjanjian-perjanijan yang sifatnya regionalisme, dimana akan dijelaskan lebih mendalam dalam bagian-bagian selanjutnya.

\section{Prinsip MFN Secara Terperinci.}

Article I dari GATT:

(1) With respect to custom duties and charges of any kind imposed on or in connection with importation or exportation ... any advantage, favor, ... by any contracting party to any product originating in or destined for any other country shall be accorded immediately and unconditionally to the like product originating in or destined for the territories of all other contracting parties.

Article II dari GATT:

(1)(a) Each contracting party shall accord to the commerce of the other contracting parties treatment no less favourable than that provided for in the appropriate Part of the appropriate Schedule annexed to this agreement.

\footnotetext{
${ }^{11}$ Lihat, Sayantan Gupta, Changing Faces of International Trade: Multilaterism To Regionalism, 3 J. Int'l Com. L. \& Tech. 262 (2008). See also, WTO, Doha WTO Ministerial 2001: Ministerial Declaration, WT/MIN(01))/DEC/1, tersedia di https://www.wto.org/english/thewto_e/ minist_e/min01_e/mindecl_e.htm\#rta (terakhir diakses 7 July, 2015).

12 Lihat., Id., Lihat juga, WTO, supra catatan no. 11.
} 
Melihat article I yang dimaksud dengan 'custom duties and charges' merujuk pada segala sesuatu yang diberikan di perbatasan (seperti bea masuk/tarif), serta memberikan kesempatan bersaing yang seimbang di perbatasan demi gagasan pedagangan bebas ${ }^{13}$. Perlu diperhatikan juga mengenai 'advantage' yang harus disesuaikan 'immediately and unconditonally' (secara langsung dan tanpa syarat) bagi seluruh negara partisipan lainnya. Sedangkan article II berkaitan dengan keterikatan tarif, dimana setiap negara anggota harus menyesuaikan perlakuan perdagangan yang tidak lebih merugikan kepada negara partisipan lainnya sesuai dengan jadwalnya. Kedua article ini membentuk prinsip MFN yang mengharuskan negara anggota menyesuaikan segala bentuk tindakan di perbatasan secara langsung dan tanpa syarat termasuk di dalamnya yaitu tarif, sehingga berlaku untuk seluruh negara partisipan lainnya tanpa terkecuali. Berdasarkan penjelasan ini, tampak bahwa prinsip MFN didasarkan nondiskriminasi dimana negara anggota dapat bersaing secara kompetitif dan adil.

Untuk mempermudah bagaimana prinsip MFN ini berfungsi, diilustrasikan apabila Indonesia memberikan tarif bea masuk arloji mekanik sebesar 10\% untuk Jerman, Indonesia juga harus memberikan tarif yang sama pada seluruh negara anggota WTO yang lainnya ${ }^{14}$. Sehingga arloji-arloji mekanik lainnya yang berasal dari negara lain dapat bersaing secara sehat karena diperlakukan sama di perbatasan sebelum masuk ke dalam pasar.

\section{General Exceptions (Pengecualian-pengecualian) di Bawah WT0/GATT}

Secara umum pengecualian atas kewajiban di dalam GATT dikecualikan di dalam article yang terkait, namun, terdapat juga pengecualian yang umum berlaku

\footnotetext{
${ }^{13}$ Lihat, Donald McRae, MFN In The GATT And The WTO, 7 Asian J. WTO \& Int'l Health L. \& Pol'y, 3-5 (2012).

14 Tarif masuk jam mekanik saat ini adalah $10 \%$ berdasarkan Tim Tarif Departemen Keuangan Republik Indonesia, tersedia di http://www.tarif.depkeu.go.id/Tarif/HS9Description.asp? cdsect=18\&hs2dig=91 (diakses terakhir 14 April, 2015). Namun tarif ini tidak termasuk Pajak Pertambahan Nilai (PPN) dan Pajak Pertambahan Nilai atas Barang Mewah (PPn BM).
} 
yaitu terdapat di dalam article XX dari GATT. Sebagai contoh untuk mengetahui bagaimana GATT berfungsi harus melihat articles sebagai berikut:

Article XI dari GATT:

(1) No prohibitions or restrictions other than duties, taxes, or other charges, whether made effective through quotas, import, or export licenses or other measures, shall be instituted or maintained by any contracting party on the importation of any product of the territory of any other contracting party on the exportation or sale for export of any product destined for the territory of any contracting party

(2) The provisions of paragraph 1 of this Article shall not extend to the following:

a) Export prohibitions or restriction temporarily applied to prevent or relieve critical shortages of foodstuffs or other products essential to the exporting contracting party;

b) Import and export prohibitions or restrictions necessary to the application of standards or regulations for the classification, grading, or marketing of commodities in international trade;

c) Import restrictions on any agricultural or fishers product, imported in any form, necessary to the enforcement of governmental measures which operate:

Berdasarkan article ini terlihat bahwa GATT tidak menghendaki para pihak di dalam perjanjian ini untuk memberlakukan kuota melainkan tarif sebagai proteksi di perbatasan. Hal ini diperkuat dalam kasus Turkey-Tekstile, dengan menyatakan bahwa the prohibition against quantitative restriction is a reflection that tariffs are GATT's border protection 'of choice'15. Restriksi kuantitatif membatasi impor secara absolut sedangkan tarif tidak ${ }^{16}$. Tarif memberikan efisiensi dalam kompetisi untuk menyediakan impor dibanding dengan restriksi kuantitatif yang biasa memiliki efek distorsi bagi perdagangan dan alokasinya pun

\footnotetext{
${ }^{15}$ Lihat, WTO, WTO Analytical Index: Guide To WTO Law And Practice - General Agreement On Tariffs And Trade 1994, World Trade Organization, point 838, tersedia di https://www.wto.org/ english/res_e/booksp_e/analytic_index_e/gatt1994_05_e.htm\#article11 (terakhir diakses 26 April, 2015).

16 Id.
} 
terkadang mengandung permasalahan, serta pelaksanaannya bisa tidak transparan ${ }^{17}$.

Terdapat pengecualian di dalam article yang sama, yang memperbolehkan pemberlakukan kuota, selama itu untuk mengurangi kekurangan produk yang esensial secara sementara, penerapan standar atau regulasi untuk klasifikasi, penilaian, pemasaran komoditas di pasar internasional, atau untuk menjaga posisi finansial secara eksternal, neraca pembayaran, dan lain-lain ${ }^{18}$.

Article XX dari GATT - Sebagai general exceptions

Subject to the requirement that such measures are not applied in manner which would constitute a means or arbitrary or unjustifiable discrimination between countries where the same conditions prevail or a disguised restriction on internal trade, nothing in this Agreement shall be construed prevent the adoption or enforcement by any contracting party of measures:

a) necessary to protect public morals;

b) necessary to protect human, animal, or plant life or health

c) relating to the importation or exportation of gold or silver

d) necessary to secure compliance with laws or regulations which are not inconsistent with the provisions of this Agreement, including those relating to customs enforcement, the enforcement of monopolies operated under ..., the protection of patents, trade marks, and copyrights, and the prevention of deceptive practices;

e) $-(\mathrm{j})$...

Pemenuhan atas ketentuan ini memerlukan tes 2 (dua) lapis (two tiered test) yaitu, (1) aksi yang diambil oleh pihak dalam perjanjian ini memenuhi karakter berdasarkan salah satu subparagraf (a)-(j) dan preambelnya ${ }^{19}$. Pemenuhan kualifikasi atas preambel di dalam artikel ini dapat dilakukan selama tindakan pemerintah tidak: (1) menimbulkan diskriminasi yang sewenang-

\footnotetext{
${ }^{17} \mathrm{Id}$.

18 Pengeculian posisi finansial secara eksternal dan neraca pembayaran terdapat di dalam article XII dari GATT.

${ }^{19}$ Lihat, Christoph T. Feddersen, Focusing On Substantive Law In International Economic Relations: The Public Morals Of GATT's Article XX(a) And "Conventional" Rules Of Interpretation, 7 Minn. J. Global Trade, 92 (1998).
} 
sewenang atau tidak dapat dijustifikasi di antara negara-negara dimana kondisi yang sama berlaku atau (2) restriksi atas perdagangan internal yang sembunyisembunyi.

Contoh sederhana pemenuhan ketentuan subparagraf dalam article ini adalah dengan melihat kasus Thailand-Cigarettes dan EC (European Communites)-Asbestos. ${ }^{20}$ Dalam kasus Thailand-Cigarettes, Panel tidak mempertimbangkan secara mendalam untuk menerima argumen Thailand bahwa restriksi impor atas rokok adalah untuk melindungi publik dari bahan-bahan berbahaya yang terkandung di dalam rokok yang diimpor dan untuk membatasi konsumsi rokok di Thailand 21 . Senada dengan hal itu, di dalam EC-Asbestos, Appellate Body memvalidasi justifikasi EC di bawah article XX (b) yang menyatakan bahwa larangan atas produk chrysotile-cement diperlukan untuk melindungi nyawa dan kesehatan manusia ${ }^{22}$. Sedangkan untuk sub paragraf (a) pemenuhan atas ketentuan ini menjadi sulit karena ketiadaan panduannya. Namun dapat disimpulkan bahwa tujuannya adalah untuk secara efektif melindungi kedaulatan negara atas kewajiban-kewajiban GATT yang intrusif23.

Kemudian, hal yang tak kalah penting untuk diperhatikan adalah kata 'necessary' (perlu) yang artinya sebuah tindakan tidak dapat dikualifikasikan sebagai 'perlu' apabila terdapat alternatif lain yang tidak konsisten dengan provisi-provisi lain dari GATT sebagai negara anggota GATT yang seyogiyanya diharapkan untuk melaksanakan tindakan alternatif tersebut ${ }^{24}$. Sehingga, tidak

${ }^{20}$ Lihat, generally., WTO, Dispute Settlement: DS371 - Thailand - Customs And Fiscal Measures On Cigarettes From The Philippines, tersedia di https://www.wto.org/english/tratop_e/dispu_e/ cases_e/ds371_e.htm (terakhir diakses 26 April, 2015). See also generally, WT0, Dispute Settlement: DS135 - European Communities - Measures Affecting Asbestos And Products Containing Asbestos, tersedia di https://www.wto.org/english/tratop_e/dispu_e/cases_e/ ds135_e.htm (terakhir diakses 26 April, 2015).

${ }^{21}$ Lihat, Yengkong Nganjoh-Hodu, Relationship Of GATT Article XX Exceptions To Other WTO Agreements, 80 Nordic J. Int'l L., 223 (2011).

22 Id.

${ }^{23}$ Lihat, Feddersen, supra catatan no. 19, pada 78.

${ }^{24}$ Lihat, Salman Bal, International Free Trade Agreements And Human Rights: Reinterpreting Article XX Of The GATT, 10 Minn. J. Global Trade, 98 (2001). 
secara langsung mempergunakan pengecualian dalam artikel ini, sebelum menggunakan tindakan alternatif yang tersedia secara layak ${ }^{25}$.

\section{Prinsip-Prinsip Fundamental dan Pengecualian dalam WT0/GATT: Regionalisme Pada Umumnya dan Kehadirannya Di Asia Tenggara.}

\section{Regionalisme}

Regionalisme kerap didefinisikan sebagai paham atau kecenderungan untuk mengadakan kerjasama yang erat antar negara di satu kawasan. ${ }^{26}$ Berdasarkan definisi sebelumnya, hal yang relevan dengan penelitian ini adalah mengenai kerja sama dalam bentuk integrasi ekonomi dan juga sebuah kawasan yaitu kawasan Asia Tenggara yang terbentuk dalam satu wadah yaitu ASEAN.

Sebuah kawasan didefinisikan sebagai a group of countries located in the same geogprahical specific area ${ }^{27}$. Integrasi pada konteks sehari-hari diartikan sebagai aksi menggabungkan bagian-bagian yang berbeda menjadi sesuatu yang integral utuh ${ }^{28}$. Selanjutnya, integrasi ekonomi dipahami sebagai sebuah proses dimana perbatasan ekonomi dihilangkan di antara negara-negara dan atau daerah yang berpartisipasi untuk memberikan tempat bagi arus bebas barang, jasa, dan faktor-faktor produksi ${ }^{29}$. Oleh karenanya, regionalisme dalam penelitian ini didefinisikan dengan sebuah aksi negara-negara yang kerap terletak secara geografi dalam suatu wilayah untuk menyatukan dirinya menjadi sesuatu yang integral dengan cara menghilangkan perbatasan-perbatasan negara demi mendukung perdagangan internal mereka, sehingga tercipta kondisi dimana terdapat liberalisasi arus barang dan jasa untuk mengurangi biaya transaksi30.

\footnotetext{
25 Id.

${ }^{26}$ Lihat, KBBI Daring, Kamus Besar Bahasa Indonesia (KBBI), versi online / daring, tersedia di http://kbbi.web.id/regionalisme. (terakhir diakses 13 April, 2015).

27 D. Mansfield Edward and V. Milner Helen, The New Wave of Regionalism, 53.3 Int'l Org. (1999).

${ }^{28}$ Lihat, Nguyen Anh Thu and Nguyen Thi Mai Anh, ASEAN and EU Economic Integration: A Comparative Analysis, ICIRD (International Conference on International Relations and Development), (2014).

${ }^{29}$ Id.

30 Lihat, Edward, supra catatan no. 27. Regionalisme diartikan sebagai proses ekonomi dimana arus ekonomi berkembang secara pesat diantara negara-negara anggota daripada negara-
} 


\section{Munculnya Blok Asia Tenggara dan Inspirasi AEC Melalui Uni Eropa, Perbedaan-perbedaan yang Mendasar}

Pembentukan kawasan integrasi ekonomi seperti layaknya AEC bukanlah merupakan hal yang baru, di Eropa sudah terdapat Uni Eropa yang menginspirasi ASEAN, di Amerika Selatan terdapat Mercosour, di Amerika Utara terdapat NAFTA, dan lain-lain ${ }^{31}$. Dikarenakan latar belakang dan tujuan setiap blok berbeda, setiap daerah memiliki pendekatannya masing-masing terhadap regionalisme. Sebagai contoh, Uni Eropa menganut regionalism yang tertutup (closed regionalism) sehingga tampak lebih ekslusif. Sedangkan ASEAN condong kepada regionalisme terbuka karena integrasi ekonomi berdasarkan dorongan pasar, dan para negara anggotanya diberikan kebebasan untuk menetapkan tarifnya masing-masing bagi non-anggota ${ }^{32}$.

Selanjutnya, motivasi melakukan regionalisme seperti Uni Eropa disebabkan oleh perang dingin pada era tahun 1960-an dimana negara-negara harus menggantungkan dirinya ke blok barat atau ke timur. Berbeda dengan ASEAN yang motivasinya didorong atas aspirasi untuk membentuk lingkungan yang kompetitif karena terdapat shifting kekuatan ekonomi dari India dan Cina sebagai emerging market ${ }^{33}$. Perbedaan yang mendasar lainnya adalah di Uni Eropa terdapat lembaga supra nasional yang terdiri dari European Council and

negara lain yang terletak di luar wilayah. Selain itu, regionalisme juga dapat diartikan sebagai proses politik yang dikarakterkan dengan kerjasama dan koordinasi kebijakan ekonomi antar sesama negara.

31 Meskipun salah satu atau beberapa bentuk dari blok-blok yang telah disebutkan tidak berjenis seragam, namun, hal yang ingin ditekankan adalah munculnya beberapa blok perdagangan di dunia. Pelbagai bentuk integrasi ekonomi berdasarkan intensitas integrasi antara lain adalah free-trade area, custom union, common market, economic union, dan complete economic integration. See generally., Thu, supra catatan no. 28.

32 Lihat, Kiki Verico, Can ASEAN Achieve Economic Community?, Jakarta Post, http://www.eir.info/2012/10/07/asean-and-the-european-union-lessons-in-integration/ (terakhir diakses 1 Maret, 2015). See also generally, Mansfiled supra catatan no. 27. Regionalisme tertutup ini terlihat dari adanya common external tariff yaitu sebuah keadaan dimana terdapat penghilangan penghalangan perdagangan internal dan tarif yang seragam bagi non-anggota.

33 Lihat, Nopadol Rompho, et. al., Strategy Execution By Thai Large Companies for ASEAN Economic Community, 9.5 Int'l J. of Business And Management (2014). See also generally, Fujian Li and Jingsha Deng, Varieties of Regionalism: Comparison Of Europe And Southeast Asia, 10 Asian Soc. Sci., 76 (2014). 
Parliament, EU Commission (EC), dan The Court of Justice of the European Union. Sedangkan, bagi kawasan Asia Tenggara hal ini menjadi tidak mungkin oleh karena prinsip yang dianut oleh ASEAN yaitu non-interference sebagai norma yang berfokus pada konsultasi dan konsensus ${ }^{34}$.

Uni Eropa merupakan customs union yakni terdapat Common External Tariff (CET) yang berarti setiap negara anggota memiliki tarif yang sama atas negara non-anggota. Sedangkan, telah disinggung sebelumnya bahwa di dalam ASEAN, negara partisipan memiliki tarifnya masing-masing terhadap negara nonanggota layaknya seperti Free Trade Area (FTA). Namun, terdapat single market, apabila AEC diimplementasikan ${ }^{35}$. Demikian yang mengkontraskan AEC dengan Uni Eropa yaitu dimana Uni Eropa memiliki bentuk customs union sedangkan AEC merupakan FTA dengan common market atau dengan kata lain serupa dengan Uni Eropa namun mengalami penyesuaian terutama dalam hal keseragaman tarif dan lembaga-lembaga supranasional ${ }^{36}$.

\section{Komitmen Indonesia Terhadap AEC}

Komitmen Indonesia terhadap AEC adalah pembentukan satu pasar dan basis produksi agar terdapat arus bebas barang, jasa, dan investasi. Ide satu pasar dan basis produksi secara esensinya adalah memberikan konsumer di area tersebut perluasan pasar dimana mereka dapat memenuhi kebutuhan konsumsi

34 Lihat, Premier, infra catatan no. 64. Lembaga supra-nasional ini berguna untuk menyelesaikan segala konflik diantara para negara anggota dan juga sebagai lembaga legislatif bagi segala sesuatu yang berlaku regional baik ke dalam maupun ke luar batas negara. See also., Tom Ginsburg, Eastphalia And Asian Regionalism, 44 U.C. Davis L. Rev., 870 (2010-2011). Prinsip non-interference ini terdapat di dalam ASEAN Charter chapter I article 2(2)(a) yang menyatakan non-interference in the internal affairs of the other members, includes refraining from public criticism of other members, refusing to provide support or sanctuary to insurgencies against other members, and a commitment to peaceful dispute resolution in inter-state conflict.

35 Lihat, Thu, supra catatan no. 28. FTA terbentuk apabila negara-negara anggota menghilangkan tarifnya bagi sesama negara anggota namun tetap mempertahankan kebijakan tarif bagi negara non-anggota. Keseragaman tarif di setiap negara anggota bagi non-negara anggota ditermakan customs union. Common market terbentuk apabila semua bentuk diskriminasi ekonomi dihilangkan terhadap pemasok asing diantara negara-negara partisipan.

36 Lihat, Thu, supra catatan no. 28 (single market dan common market). Berdasarkan jurnal ini, single market dan common market sangat serupa sehingga untuk mengurangi argumen atas terma, dalam penelitian ini akan disamakan. 
dan produsen di wilayah tersebut dengan juga perluasan ruang darimana mereka dapat menjalani produksi mereka tanpa harus mengkhawatirkan perbatasan nasional di wilayah tersebut ${ }^{37}$. Untuk mendukung hal tersebut, diperlukan bukan hanya tarif yang mencapai $0 \%$ namun juga penghilangan non-tariff barriers $^{38}$. Selain cetak biru AEC, terdapat pula komitmen-komitmen lain yang terdapat di dalam perjanjian-perjanjian regional lainnya, salah satunya adalah ASEAN Trade In Goods Agreement (ATIGA) sebagai building blocks dari AEC 39 .

Disebut building blocks karena di dalamnya terdapat prinsip MFN dan Rules Of Origin (ROO) yang akan berguna bagi pembahasan selanjutnya. Prinsip MFN di dalam ATIGA pada intinya serupa dengan prinsip MFN dalam WTO, namun perbedaannya adalah wilayah berlakunya dimana MFN di dalam ATIGA hanya berlaku bagi negara-negara partisipan ASEAN. Prinsip MFN di dalam ATIGA menyatakan bahwa apabila salah satu negara anggota memiliki perjanjian dengan negara bukan anggota dimana komitmennya lebih menguntungkan daripada yang disebutkan di dalam perjanjian ini, negara anggota yang lain dapat meminta untuk bernegosiasi dengan negara anggota terkait, dalam rangka menginkorporasikan perlakuan yang lebih baik daripada yang disebutkan di bawah perjanjian yang disebutkan sebelumnya ${ }^{40}$.

Kemudian, ROO digunakan untuk mengetahui dari mana asal produk tersebut, untuk menentukan apakah produk tersebut mendapatkan perlakuan

37 Lihat, Myrna S. Austria, Moving Towards An ASEAN Economic Community, 29 East Asia , 142 (2012). See also, Peter J. Llyod, What Is A Single Market? An Application To The Case of ASEAN, 22.3 ASEAN Economic Bulletin, 252 (2005) (Mengenai single market). The central idea of a single market is that there should be no discrimination according to source in the regional market for goods, services, or factors, thus, creating a market that should be single market with no geographical segmentation.

38 Lihat, AEC Blueprint, point. 10. See also., Austria, supra catatan no. 37, pada 143. 8 sektor prioritas barang yaitu (1) produk-produk agrikultural, (2) perikanan, (3) kesehatan, (4) berasal dari karet, (5) berasal dari kayu, (6) tekstil dan garmen, (7) elektronik, informasi, dan komunikasi, dan (8) automotif. Non-tariff barriers dalam hal ini segala bentuk kebijakan atau regulasi yang dapat meristriksi masuknya barang (impor).

39 Ditandatangani di Cha-am Thailand pada tanggal 26 Februari 2009. See., ASEAN Trade in Goods (ATIGA), ASEAN countries, tersedia di http://www.asean.org/images/2012/ Economic/ AFTA/annex/ASEAN\%20Trade\%20in\%20Goods\%20Agreement,\%20Cha-am,\%20Thailand ,\% 2026\%20February\%202009.pdf (terakhir diakses 10 Juni, 2015).

40 Lihat, ATIGA, art. 5. 
khusus seperti yang terdapat di dalam komitmen AEC atau ATIGA ${ }^{41}$. Untuk mendapatkan perlakuan khusus tersebut seperti misalnya tarif 0\%; produkproduk tersebut harus: (1) berasal atau diproduksi dari negara anggota yang mengekspor atau (2) tidak berasal atau diproduksi dari negara anggota yang mengekspor namun memenuhi kriteria tertentu ${ }^{42}$. Sehingga memunculkan sebuah asumsi bahwa Singapore akan menjadi pintu belakang bagi masuknya barangbarang ke ASEAN. Hal ini tidak dimungkinkan, karena setiap produk atau barang hanya terhubung dengan pada satu certificate of origin dan untuk mendapatkan perlakuan seperti itu, diharuskan terdapat perubahan pada 4 digit dalam Harmonized System (HS code) atau perubahan pada klasifikasi barang seperti misalnya kulit sapi menjadi tas kulit.

\section{Penghalang (Stumbling Block) atau Pijakan (Building Block) atas Agenda WTO.}

Dalam pemaparan terakhir, isu regionalisme akan fokus pada mengapa regionalisme dipilih oleh banyak negara, serta, apakah regionalisme menjadi penghalang atau batu pijakan bagi globalisasi/multilateralisme. Selain itu alasan mengapa banyak negara menyandarkan diri pada regionalisme yang dimulai pada saat WTO tidak dapat lagi mengembangkan liberalisasi perdagangan dan kesempatan untuk pertumbuhan bagi seluruh negara partisipan WTO, yang berimplikasi pada banyak negara yang mengambil jalur alternatif untuk liberalisasi perdagangan dan reformasi perdagangan. ${ }^{43}$ WTO tidak dapat mencapai

41 Dalam sistem ekspor dan impor terdapat yang dinamakan dengan certificate of origin (CoO) untuk menentukan asal barang tersebut dan setiap produk hanya berkoresponden pada satu sertifikat.

42 Lihat, ATIGA., art 26. See also., ATIGA, art. 28 dan 29 (kriteria barang yang mendapatkan perlakuan khusus tapi tidak diperoleh atau diproduksi dari negara anggota). Secara sederhana kriteria tersebut dipenuhi apabila setelah diproses di ASEAN nilainya tidak kurang dari 40\% dari Regional Value Content (RVC) atau mengalami perubahan dari klasifikasi tarif pada 4 digit sesuai dengan Harmonized System (HS Code). Terdapat 2 cara untuk menghitung RVC namun di dalam perjanjian ini sebuah negara hanya boleh memilih satu cara. Sebagai contoh dengan menggunakan Indirect Method yaitu RVC = (FOB Price - Value Of Non-Originating Materials, Parts, or Goods) / FOB price X 100\%).

43 Lihat, C. O’Neal Taylor, Regionalism: The Second-Best Option?, 28 St. Louis U. Pub. L. Rev, 156 (2008-2009). 
konsensus di antara para anggotanya untuk reformasi perdagangan-Doha Rounddan mendatangkan banyak kesulitan pada negara-negara untuk mencapai kesepakatan dalam perjanjian-perjanjian regional karena faktanya adalah pemerintahan mereka lebih familiar dengan negara tetangganya dibandingkan dengan negara yang jauh ${ }^{44}$. Selain itu, regionalisme digunakan sebagai pilihan yang terbaik bagi mayoritas negara anggota WTO karena regionalism menarik kedua blok baik yang mengkritisi WTO karena tidak berani terlalu jauh khususnya mengenai komitmen akan investasi, standar tenaga kerja, kompetisi, dan lingkungan hidup, maupun, sisi lain yang mengeluh karena bertindak terlalu jauh dengan memaksa mereka untuk menerima kewajiban yang bukan merupakan kepentingan mereka dan di luar kapasitas mereka untuk mengimplementasikannya ${ }^{45}$. Inilah mengapa regionalisme lebih dipilih dibandingkan dengan multilateralisme yang mengarah kepada globalisasi.

WTO adalah wadah untuk perjanjian-perjanjian multilateral yang masif, dimana semua negara bergabung pada persetujuan yang global yang menerapkan penghapusan tarif bagi mereka yang menginginkan untuk berpartisipasi 46 . Kiranya, tidaklah berlebihan apabila mengkategorikan multilateralisme dengan globalisasi yang memiliki karakter utama dengan menipisnya perbatasanperbatasan geografi (batas negara) atas aktifitas ekonomi yang menjadi satu wadah yang luas ${ }^{47}$. Multilateralisme tersebut tidak dapat diterima oleh seluruh anggota mengingat bahwa kebanyakan dari negara anggota merupakan negara berkembang dan bukan negara maju. Apabila dikorelasikan dengan logika yang disebutkan sebelumnya, negara berkembang dapat memilih pelbagai cara untuk memasuki perekonomian dunia, yaitu: (1) insersi yang sifatnya unilateral dengan cara partisipasi atas upaya multilateral yang memiliki tujuan liberalisasi

${ }^{44}$ Lihat, Chris Brummer, The Ties That Bind? Regionalism, Commercial Treaties, And The Future of Global Economic Integration, 60 Vand. L. Rev., 1359 (2007). See also, Trost, infra catatan no.68, pada 195 (Mengenai kegagalan Doha Round).

45 Lihat, Alberta Fabbricotti, The Paradox Of Multilateralizing Regionalism Through Flexibility, 103 Am. Soc'y Int'l L. Proc., 120 (2009).

${ }^{46}$ Lihat, Brummer, supra catatan no. 44, pada 1359.

47 Lihat, Taufiqurrahman, infra catatan no. 63, pada 30. 
perdagangan seperti yang dikelola oleh WTO atau (2) insersi melalui partisipasi di dalam bilateral atau minilateral kooperasi ekonomi dengan negara-negara lain ${ }^{48}$.

Maka, jelaslah bahwa dengan nalar pun akan terlihat bahwa sebelum masuk ke perdagangan global yang sangat liberalis, tentu banyak negara lebih memilih jalan regionalisme sebagai pengenalan dan perlindungan dari arus globalisasi. Berdasarkan pakta yang terikat geografi tersebut - dimana negara dapat menghindari kewajiban umum WTO atas non-diskriminasi yang nantinya akan di bahas di bagian selanjutnya - negara-negara terpilih dapat berkomitmen untuk mengadopsi peraturan-peraturan atau prinsip-prinsip hukum yang umum sehubungan dengan perlakuan khusus bagi produk-produk dari negara anggota lainnya yang terkait pada level minimum ${ }^{49}$. Partisipan mendapatkan keuntungan atas barang-barang yang lebih murah, spesialisasi yang lebih efisien, dan kesempatan untuk mengindustrialisasi di belakang perbatasan yang proteksionis ${ }^{50}$. Kemudian, apabila ini menjadi langkah yang terbaik, bagaimana WTO menanggapinya?

WTO mengakui keberadaan pengaturan seperti ini namun dengan persyaratan yang ketat sebagaimana nanti dibahas lebih mendalam dalam bagian berikutnya. Hal ini dikarenakan negosiasi perdagangan WTO yang lambat dan biasa terjadi dalam perdebatan pandangan yang berbeda antara negara berkembang dengan negara maju dan terkadang oleh sesama negara maju maupun negara berkembang51. Atas kegagalan kesepakatan tersebut, WTO memberikan kompromi atas regionalisme yang tertuang dalam article XXIV dari GATT. Hal ini menjadi logis, yaitu dengan tidak tercapai persetujuan, WTO memilih untuk mengakui regionalisme dibanding tidak ada liberalisasi

\footnotetext{
${ }^{48}$ Lihat, Horagaio A. Grigera Naon, Sovereignty And Regionalism, 27 Law \& Pol'l Int'l Bus., 1074 (1995-1996).

${ }^{49}$ Lihat, Brummer, supra catatan no. 44., pada 1355-1356

50 Id.

${ }^{51}$ Lihat, Matsushita, infra catatan no. 59, pada 192.
} 
perdagangan sama sekali dengan harapan bahwa nantinya akan menjadi batu loncatan atas multilateralisme 52 .

Sebagai batu loncatan atau penghalang atas globalisasi, hal tersebut di atas secara disiplin ekonomi terdapat beberapa persyaratan yang harus dipenuhi, yakni (1) trade creation, yaitu keuntungan bagi para negara anggota setelah terbentuknya perjanjian yang membentuk regionalisme seperti kenaikan perdagangan yang bersifat intra-regional, dan (2) trade diversion, yaitu kerugian ekonomi yang diderita oleh pihak ketiga sebagai hasil dari para negara anggota yang membentuk blok perdagangannya akibat dari kehilangan perdagangan antara pihak ketiga dengan salah satu negara anggota terkait sebagai mitra dagangnya ${ }^{53}$. Akibat kedua hal ini tampak bahwa regionalisme adalah karakter dari economic interdependence (ketergantungan ekonomi) yang tinggi dan keberadaan kerangka kerja multilateralisme ${ }^{54}$. Selain ketergantungan ekonomi yang hadir di perjanjian pembentukan blok-blok perdagangan, terdapat pula liberalisasi perdagangan di dalamnya. Kesimpulannya WTO mengakui adanya regionalisme yang diakibatkan atas kegagalannya pun, mengakibatkan diskriminasi di luar blok-nya. Namun, karena terdapat pengaruh WTO di dalam regionalisme seperti economic interdependence, liberalisasi perdagangan, dan prinsip MFN, maka WTO memberikan kompromi atas pembentukan perjanjian seperti itu yang akan dijelaskan dalam bagian selanjutnya secara mendetil. Atau dengan kata lain, WTO mengkehendaki regionalisme yang membantu arus perdagangan yang lebih bebas diantara negara-negara partisipan tanpa harus menetapkan penghalang baik bagi negara-negara anggota yang terikat maupun negara-negara di luar pengaturan seperti itu, dengan harapan dapat melengkapi perdagangan multilateral dan bukan menjadi ancaman bagi negara-negara ${ }^{55}$.

\footnotetext{
52 Lihat, WTO, Understanding The WTO, Regionalism: Friends Or Rivals?, Cross-Cutting And New Issues, tersedia di https://www.wto.org/english/thewto_e/whatis_e/tif_e/bey1_e.htm (diakses terakhir 21 April, 2015).

53 Lihat, Stephen Joseph Powell And Trisha Low, Is The WTO Quietly Fading Away?, The New Regionalism And Global Trade Rules, 9 Geo. J. L. \& Pub. Pol'y, 264 (2011).

${ }^{54}$ Lihat, Id., 263.

55 Lihat, WTO, supra catatan no. 52.
} 


\section{Interpretasi Kompromi WTO atas Regionalisme Melalui Manifestasi Blok- blok Perdagangan}

Article XXIV dari GATT merupakan pengakuan WTO atas regionalisme sebagai bentuk kompromi. Sebagai bentuk kompromi maka artikel ini juga merupakan payung hukum pembentukan blok-blok perdagangan yang ada saat ini. Penting untuk membahas ketentuan tersebut mengingat bahwa pelanggaran terhadap artikel ini akan memberikan konsekuensi untuk dibawanya Indonesia atau negara ASEAN lainnya ke Dispute Settlement Body (DSB) WTO.

Dalam hal ini, WTO hanya mengacu pada pembentukan dan bukan operasional perjanjian-perjanjian regional56. Secara sederhana, Article XXIV terbagi atas 3 bagian inti, payung hukum perjanjian-perjanjian regional yang membentuk regionalisme yang tertuang di dalam paragraf (4) dan, syarat-syarat eksternal dan internal yang tertuang dalam paragraf (5) dan (8) respectively57.

\section{Article XXIV (4) GATT:}

The contracting parties recognize the desirability of increasing freedom of trade by development, through voluntary agreements, of closer integration between the economies parties to such agreements. They also recognize that the purpose of a customs union or of a free-trade area should be to facilitate trade between the constituent territories and not to raise barriers to the trade of other contracting parties with such territories.

Article XXIV(5) GATT:

Accordingly, the provisions of this Agreement shall not prevent ...., the formation of a customs union or of a free-trade area or the adoption of an interim agreement necessary for the formation of a customs union or of a free-trade area;

(a) With respect to customs union or an interim agreement leading to a formation of a customs union, the duties and other regulations of commerce imposed at the institution .... in respect of trade with contracting parties not parties to such union or agreement shall not

\footnotetext{
56 Lihat, Sungjoon Cho, Breaking The Barrier Between Regionalism And Multilateralism: A New Perspective On Trade Regionalism, 42 Harv. Int'l L. J., 421 (2001).

57 Id.
} 
on the whole be higher or more restrictive than ... the duties and regulations of commerce applicable in the constituent territories prior to the formation of such union ...., as the case may be;

(b) With respect to free-trade area, or an interim agreement leading to the formation of a free-trade area, the duties and other regulations of commerce maintained in each of the constituent countries and applicable at formation of such free-trade area ... to the trade of contracting parties not included in such area ... shall not be higher or more restrictive than the corresponding duties and other regulations of commerce existing in the same constituent territories prior to the formation of free-trade area, ... and;

(c) Any interim agreement referred to in subparagraphs (a) and (b) shall include a plan and schedule for the formation of such customs union or such of a free-trade within a reasonable length of time.

\section{Article XXIV (8) GATT58:}

(a) A customs union shall be understood to mean the substitution of a single customs territory for two or more customs territories, so that

i. Duties and other restrictive regulations of commerce ... are eliminated with respect to substantially all trade between the constituent territories of the union or at least with respect to substantially all the trade in products originating in such territories and,

ii. ..., substantially the same duties and other regulations of commerce are applied by each of the members of the union to the trade of territories not included in the union.

(b) A free-trade area shall be understood to mean a group of two or more customs territories in which the duties and other restrictive regulations of commerce ... are eliminated on substantially all the trade between the constituent territories in products originating in such territories.

Article XXIV (4) melafalkan prinsip umum dari tujuan dibentuknya customs union atau free-trade area, yaitu untuk mendukung perdagangan di antara para partisipan dan tidak membentuk penghalang dagang bagi negara-negara non-

58 Penting untuk diperhatikan bahwa dalam article ini beberapa restriksi diperbolehkan selama memenuhi article XI,XII,XIII, XIV, XV, XX). See also., Michael Ewing-Chow, ASEAN Integration, The Rule Of Law, And Investment Agreements, 107 Am. Soc'y Int'l L. Proc., 289 (2013) (Mengenai article XX dari GATT). Dimana article XX menyatakan bahwa di dalam perjanjian ini, tidak ada yang menghalangi salah satu pihak untuk mengadopsi atau memberlakukan tindakan-tindakan tertentu yang menyangkut areal sensitif. 
anggota $^{59}$. Hal ini menandakan bahwa WTO memberikan kompromi atas pendirian blok-blok perdagangan dengan syarat-syarat yang ketat ${ }^{60}$. Mengingat ketentuan ini mengandung prinsip umum, artikel ini dikategorikan sebagai payung hukum pembentukan customs union dan free-trade area. Sebagai payung hukum (corner stone/touch stone), artikel ini memuat prinsip yang ditujukan untuk memajukan perdagangan dan tidak mengharapkan proteksionisme di belakang perbatasan customs union atau pun free-trade area, serta, tidak boleh disimpangi dan mengikuti provisi-provisi setelahnya ${ }^{61}$.

Hal ini ditandai dengan kata 'accordingly' pada paragraf setelahnya. Di mana, dalam paragraf ini, dikukuhkan kompromi atas regionalisme yang menyatakan bahwa ketentuan-ketentuan dalam GATT tidak menghalangi manifestasi blok-blok perdagangan, selama memenuhi ketentuan-ketentuan eksternal yang terdapat dalam provisi ini. Ketentuan eksternal bagi customs union terdapat dalam subparagraph (a) sedangkan bagi free-trade area terdapat dalam sub paragraph (b). Syarat eksternal ini mengkehendaki bahwa segala bea dan juga peraturan-peraturan yang mempengaruhi perdagangan dengan negara-negara non-blok tidak boleh lebih tinggi atau lebih restriktif daripada sebelum pembentukan customs union ataupun free-trade area.

Melihat ketentuan di atas apabila dikaitkan dengan Uni Eropa dan ASEAN, maka ASEAN akan terbentur kesulitan untuk membentuk customs union seperti di Uni Eropa. Di satu sisi, di Uni Eropa pada saat pembentukan institusi (European Comission/EC bagian Taxation and Customs Union), tidak terdapat kesulitan untuk menentukan apakah tarif eksternal (tarif yang berlaku bagi negara pihak ketiga-

59 Lihat, Mitsuo Matsushita, Regionalism And The Disciplines Of The WTO: Analysis Of Some Legal Aspects Under Article XXIV Of The GATT, 13 Asia Pac. L. Rev., 195 (2005). See also., Gupta, supra catatan no. 11, pada 262.

60 Dibuktikan dengan adanya kata 'recognize' dan syaratnya adalah 'to promote trade among the participants without establishing barriers to WTO participant countries that are not a part of it'

61 Proteksionisme di sini merujuk pada penghindaran kewajiban umum WTO yaitu MFN melalui regionalisme. Sehingga negara-negara anggota WTO yang menginginkan penghindaran kewajiban tersebut tidak dengan mudahnya keluar dengan cara masuk ke dalam suatu customs union atau free-trade area karena sesuai dengan prinsip ini harus ditujukan untuk mempromosikan perdagangan bebas. 
i.e. Common External Tariff) menjadi lebih tinggi atau tidak karena komitmen mereka atas WTO mengenai bea dapat diratakan dan disesuaikan ${ }^{62}$. Di sisi lain, negara-negara anggota ASEAN memiliki keragaman komitmen atas bea melalui WTO, terutama Singapura, dimana negara ini memiliki kebijakan tarif yang hampir 0\%63. Sehingga, apabila ASEAN mengkehendaki pembentukan customs union, dibutuhkan Common External Tariff (CET), namun hal ini akan menimbulkan permasalahan, yaitu mengenai penentuan tarif. Pertanyaan penentuan tarif akan berputar pada apakah negara-negara ASEAN yang lain akan mengikuti tarif Singapura yang hampir 0\% atau apakah Singapura menyesuaikan tarifnya dengan negara partisipan ASEAN lainnya64. Maka dari itu, struktur AEC, yaitu free-trade area dengan Common Market menjadi langkah yang tepat, terkait dengan ketentuan dalam GATT yang mengharuskan hasil dari free-trade area tidak mengakibatkan bea lebih tinggi atau peraturan-peraturan dagang menjadi lebih restriktif.

Berikutnya berkaitan dengan article XXIV (8) dari GATT yang membahas mengenai definisi customs union dan free-trade area, serta syarat internal yang terkandung di dalamnya untuk penafsiran atas pembentukan blok-blok perdagangan yang memiliki permasalahan tersendiri.

62 Disesuaikan dalam konteks ini sesuai dengan article XXIV (6) dari GATT yang menyatakan bahwa apabila suatu negara anggota menaikan tarifnya di atas rata-rata akibat dari pembentukan customs union, maka, harus dinegosiasikan dengan negara-negara anggota di luar customs union.

63 Lihat, Taufiqurrahman, Paradigm Of Universalistic Particularism To Reform The Indonesia Economic Law In The Framework Of Establishing The 2015 ASEAN Economic Community, 4 Juridical Trib., 31 (2014) (Keragaman yang dimaksud adalah kondisi ekonomi negara-negara anggota ASEAN yang terlalu jomplang mulai dari negara miskin yang dikelilingi daratan yaitu Laos hingga negara maju yang berbentuk pulau kecil yaitu Singapur). See also., Mindy ChenWishart, Legal Transplant And Undue Influence: Lost In Translation Or A Working Misunderstanding?, 62.1 Int. and Comp. L. Q., 5 (2013) (Singapore sebagai international hub). Singapura memiliki aspirasi untuk menjadi pusat kegiatan komersil internasional, dimana iklim ekonomi mereka sangat mendukung liberalisasi perdagangan dengan cara penjaminan atas hak-hak dalam property (benda) dan kontrak. Sehingga, kenaikan atas tarif menjadi sangat tidak mungkin bagi Singapura karena dengan menaikan tarifnya maka Singapura harus meninggalkan aspirasi ini.

64 Lihat, Siam Premier, ASEAN Economic Community And The European Union's Experience, Siam Premier International Law Office Limited, tersedia di http://siampremier.com/aseaneconomic-community-and-the-european-unions-experience/ (terakhir diakses 1 Maret, 2015). 
Article XXIV (8) (a) menyatakan bahwa kualifikasi sebuah customs union adalah substitusi sebuah entitas atas dua atau lebih daerah yang menjadi satu, di mana segala bea dan peraturan-peraturan regulasi mengenai perdagangan dihilangkan sehubungan dengan 'substantially all the trade' (seluruh perdagangan secara substansial) di antara negara-negara terkait dalam persatuan tersebut, atau sedikitnya berkaitan dengan 'substantially all the trade' dalam produk-produk yang berasal dari wilayah tersebut ${ }^{65}$. Hal lain, keseragaman secara substansial atas segala bea dan peraturan-peraturan dagang yang diaplikasikan bagi setiap negara anggota dalam kelompok negara-negara non-anggota ${ }^{66}$. Senada dengan ketentuan ini, Article XXIV (8) (b) mengatur atas free-trade area yang memiliki ketentuan internal yang serupa, namun, terdapat perbedaan, yaitu tidak terdapat keseragaman penetapan dalam hal bea dan peraturan-peraturan dagang.

Tampak bahwa syarat internal dari WTO melalui GATT mengenai regionalisme atas blok-blok perdagangan, ialah menghilangkan bea dan regulasiregulasi perdagangan sehubungan dengan seluruh perdagangan secara subtansial yang berasal negara-negara terkait. Khususnya, terkait dengan customs union harus terdapat keseragaman bea dan regulasi perdagangan bagi negara-negara non-partisipan. Atau dengan kata lain, Article XXIV dari GATT memperbolehkan pembentukan blok-blok perdagangan selama: (1) dapat menurunkan tarif bagi seluruh barang perdagangan secara substansial hingga ke tarif hampir $0 \%$ bagi perdagangan intra-regional; (2) terdapat periode transisi yang pendek; dan (3) tidak meningkatkan hambatan atas perdagangan dengan negara-negara di luar

65 Lihat, art XXIV(8)(a)(i) dari GATT.

66 Lihat, article XXIV(8)(b)(ii) dari GATT. Keseragaman ini dinamakan dengan CET (Common External Tariff) yang berarti terdapat keseragaman tarif di dalam suatu customs union bagi negara non-anggota dalam perseketuan. Sebagai contoh apabila di Prancis memiliki tarif 5\% atas pakaian jadi maka di Jerman juga akan dikenakan tarif yang sama mengingat bahwa kedua negara tersebut termasuk dalam suatu customs union yang bernama Uni Eropa (European Union). 
kelompok (rata-rata tarif tidak boleh lebih tinggi daripada sebelum pembentukan dilaksanakan) ${ }^{67}$.

Berkaitan dengan seluruh perdagangan secara substansial ('substantially all trade'), maka timbul pertanyaan, apa yang dimaksud dengan 'substantially all trade'? Apakah ditentukan secara kualitatif atau kuantitatif?

Pendekatan kuantitatif merujuk pada patokan statistik seperti persentase perdagangan di antara negara-negara terkait, misalnya perdagangan antara negara $\mathrm{X}$ dan $\mathrm{Y}$, dimana $10 \%$ dari total perdagangan yang diliberalisasikan merupakan perdagangan agrikultural. Apabila terdapat restriksi atas produk agrikultural pada suatu perjanjian regional, hal ini tidak akan dikualifikasikan sebagai 'substantially all trade'; sedangkan, pendekatan kualitatif merujuk pada persyaratan bahwa tidak ada satu sektor pun (atau setidaknya tidak ada di sektor mayor) yang dikecualikan dalam intra perdagangan yang diliberalisasikan dalam sebuah pembentukan blok perdagangan. Apabila dalam hal ini produk agrikultural dikecualikan, akan melanggar ketentuan atas persyaratan internal pembentukan perjanjian regional ${ }^{68}$. Bilamana, pendekatan kuantitatif dan kualitatif digunakan, meskipun liberalisasi perdagangan secara internal mencapai 90\% (secara kuantitatif) tidak serta merta membuat pembentukan perjanjian regional menjadi sah. Karena harus melihat sektor ekonomi apa yang dikecualikan (secara kualitatif), namun, secara gramatikal mungkin diperbolehkan sebuah pengecualian dengan melihat bahwa penulisan teks article XXIV(8) (b) adalah

67 Lihat, Michael G. Plummer, ASEAN And The Theory Of Regional Economic Integration: A Survey, 14.2 ASEAN Econ. Bulletin, 204 (1997). Meskipun sebelumnya, masa transisi tidak dibahas secara rinci baik sebelumnya atau setelahnya. Namun, disinggung pada pemaparan article XXIV(5)(c). Interim agreement adalah perjanjian/komitmen menuju pembentukan customs union atau free-trade area. Durasi masa transisi ini berlangsung hingga paling lama 10 tahun. See also., WTO, The Basic Rules For Goods - Regional Trade Agreements - Goods Rules, The World Trade Organization (WTO), tersedia di https://www.wto.org/english/tratop_e/ region_e/regatt_e.htm (terakhir diakses 16 April, 2015) (the reasonable length of time should exceed 10 years only in exceptional cases).

68 Lihat, Fred Trost, Reconciling Regional Trade Agreements With The Most Favoured Nation Principle In WTO-GATT, 5 Macquarie J. Bus. L., 61 (2008). Lihat juga, Matsushita, supra catatan no. 59, pada 195 . 
'substantially all of trade' dan bukan 'substantially all products'69. Sehingga, terlihat bahwa pendekatan seperti di atas tidak memberi penjelasan atas klarifikasi apakah yang dimaksud dengan perdagangan secara substansial.

Untuk mempertegas permasalahan atas interpretasi tersebut, diperlukan analisis lebih dalam melalui case yang pernah dibawa ke WTO yang hingga saat ini menjadi landmark decision bagi kompromi WTO atas regionalisme yaitu Turkey Tekstile dan dikombinasikan dengan Understanding Article XXIV yang disusun oleh WTO. Dalam kasus Turkey Tekstile, Turki memberikan restriksi kuantitatif impor atas tekstil dan pakaian tertentu yang berasal dari India yang bertentangan dengan prinsip MFN ${ }^{70}$. Turki memberikan argumentasi atas pengenaan tindakan seperti itu demi implementasi dari customs union dengan European Community, sehingga dijustifikasi oleh article XXIV dari GATT ${ }^{71}$. Dalam hal ini, Appellate Body WTO mengindentifikasi paragraf (4) sebagai elemen yang penting dalam interpretasi paragraf (5) dengan kata 'accordingly' atau dengan kata lain paragraf (4) mengikuti provisi-provisi berikutnya ${ }^{72}$. Berdasarkan provisi paragraf (4), tujuan dibentuknya customs union adalah untuk 'memfasilitasi perdagangan' di antara negara-negara terkait dan 'tidak memberikan hambatan perdagangan' bagi negara ketiga ${ }^{73}$. Ini merupakan permintaan (syarat) obyektif atau tes bertujuan (objective test) ${ }^{74}$. Maka, paragraf (4) sebagai jiwa (payung hukum) dari article XXIV yang menjembatani artikel berikutnya, penyimpangan dari prinsip MFN dapat dibenarkan selama tindakan yang dipertanyakan mengakibatkan customs

69 Lihat, Matsushita, supra catatan no. 59, pada 195.

70 Lihat, McRae, supra catatan no. 13, pada 11-12.

71 Lihat, Id., Provisi yang ditantang adalah article XXIV(5) dari GATT yang menyatakan bahwa “... the provisions of this Agreement shal not prevent ...., the formation of a customs union or of a freetrade area or the adoption of an interm agreement"

72 Lihat, WTO, WTO Analytical Index: Guide To WTO Law And Practice - General Agreement On Tariffs And Trade 1994, point 999. Selain itu, Appellate Body merupakan badan tertinggi dari DSB WTO sebagai hasil dari proses banding apabila keputusan panel WTO dirasa tidak memuaskan.

73 Lihat, Id., point 1000.

74 Penggunaan tes seperti ini sangat condong kepada sistem Common Law dimana dalam memberikan rationale yang berujung pada keputusan suatu case oleh hakim atau dalam hal ini panel berdasarkan tes seperti balancing test, objective test, dan prongs. 
union tidak dapat dibentuk ${ }^{75}$. Hal ini diperkuat dengan pernyataan Appellate Body yaitu bahwa provisi-provisi dalam GATT 1994 tidak dapat dibaca sebagai sesuatu yang menyebabkan pembentukan customs union tidak dimungkinkan ${ }^{76}$. Sehingga, untuk memenuhi persyaratan artikel ini, diperlukan: (1) pembuktian bahwa formasi customs union memenuhi syarat dalam article XXIV(8) (a) dan article XXIV (5) (a) dari GATT; dan (2) pembentukan customs union dapat dicegah apabila tidak dapat melakukan langkah atas permasalahan yang ada77.

Diaplikasikan pada kasus Turkey Tekstile, Turki harus menunjukan: (1) pengaturan dengan Uni Eropa harus merupakan customs union yang valid; (2) tindakan atas restriksi pada perdagangan tersebut diadopsi pada saat formasi customs union; dan (3) merupakan hal terpenting, bahwa formasi customs union seperti itu menjadi tidak mungkin tanpa adanya restriksi impor atas tekstil dari India $^{78}$. Kesimpulannya, Turki dapat mengadopsi pengaturan rules of origin sebagai alternatif atas tindakannya dengan restriksi kuantitatif ${ }^{79}$.

Telah disinggung sebelumnya tentang article XXIV(8) (a) dari GATT dalam kasus Turkey Tekstile. Interpretasi WTO mengenai 'substantially all the trade' berdasarkan Appellate Body yakni neither GATT CONTRACTING PARTIES nor the WTO Members have ever reached an agreement on the interpretation of the term 'substantially' in this provision ${ }^{80}$. Namun, tidak berarti term tersebut menjadi kabur selamanya karena diberikan sebuah fleksibilitas, dimana fleksibilitas tersebut

75 Lihat, McRae, supra catatan no. 13, pada 11-12.

${ }^{76}$ Lihat, WTO, supra catatan no. 72, point 1030. See also., Warren H. Maruyama, Preferential Trade Arrangements And The Erosion Of The WTO'S MFN Principle, 46 Stan. J. Int'l L., 181 (2010). Secara sederhana dalam paragraf (5)(a), manifestasi sebuah customs union tidak dapat menyebabkan kenaikan pada tarif umum (yang dirata-ratakan). Kemudian paragraf (5)(b) menyatakan bahwa bea dan regulasi-regulasi lainnya tidak boleh lebih tinggi atau lebih restriktif yang eksis terlebih dahulu sebelum pembentukan customs union ataupun free-trade area. Senada dengan hal itu, sebuah perjanjian dagang regional tidak dapat diikuti dengan kenaikan bea yang spesifik sebagai hambatan bagi pihak ketiga, sehingga, tidak dapat menggunakan perjanjian tersebut sebagai alasan untuk menaikan bea yang spesifik atas barang yang spesifik.

77 Lihat, WTO, supra catatan no. 72., point 1001-1008.

78 Id.

79 Lihat, Maruyama, supra catatan no.76, pada 187. Maka telahlah jelas bahwa penjelasan dalam Rules of Origin (ROO) berguna untuk menghindari dibawanya Indonesia ke DSB WTO.

80 Lihat, WTO, supra catatan no.72, point 1030-1331 
dibatasi oleh syarat bahwa bea dan segala macam regulasi yang merestriksi perdagangan dihilangkan sehubungan dengan seluruh perdagangan internal secara substansial ${ }^{81}$. Intrepretasi tersebut dapat diaplikasikan pada kasus Turkey Tekstile, dimana Turki beragumentasi bahwa tanpa mengadopsi restriksi tersebut European Communities akan mengecualikan produknya karena ekspor produk tersebut ke Uni Eropa berkontribusi sebesar 40 persen dari total perdagangan tekstil, sehingga Turki khawatir tidak dapat memenuhi 'substantially all the trade' tanpa tindakan seperti itu. Namun, argumentasi tersebut ditolak oleh karena Turki dapat mengadopsi Rules Of Origin untuk tekstil dan pakaian sehingga produkproduk tersebut dapat membedakan antara produk Turki dan produk dari India, dimana arus bebas perdagangan dapat dinikmati oleh produk dari Turki ${ }^{82}$. Maka terlihat bahwa kompromi WTO dalam fleksibilitas mengenai seluruh perdagangan secara substansial adalah mengenai ada atau tidaknya alternatif yang lebih baik. Selain itu, dapat juga dikatakan bahwa yang dimaksud dengan 'substantially all the trade' adalah tidak sama dengan semua perdagangan tapi sesuatu yang lebih daripada sekedar beberapa perdagangan ${ }^{83}$.

Kunci dalam menginterpretasi kompromi WTO mengenai regionalisme adalah: (1) apakah perjanjian yang bersifat regionalisme tersebut melengkapi perdagangan dunia?; (2) tidak menggunakan perjanjian tersebut sebagai pintu keluar untuk menghindari prinsip MFN; dan (3) memenuhi syarat-syarat dalam article XXIV dari GATT, dimana memenuhi: (i) tujuan pembentukan customs union atau free-trade area adalah untuk mendukung perdagangan antara negara-negara partisipan dan tidak menimbulkan hambatan bagi pihak di luar perjanjian tersebut; (ii) syarat eksternal yaitu setiap bea dan regulasi-regulasi perdagangan tidak boleh lebih restriktif daripada sebelum terbentuknya formasi perdagangan regional terhadap negara-negara di luar perjanjian tersebut; dan (iii) syarat internal yaitu penghilangan segala bea dan regulasi-regulasi perdagangan

\footnotetext{
$81 \mathrm{Id}$.

82 Id.

83 Lihat., McRae, supra catatan no. 13, pada 11
} 
sehubungan dengan seluruh perdagangan secara substansial yang berlaku diantara negara-negara partisipan, dimana yang dimaksud perdagangan secara substansial masih terbuka untuk diperdebatkan.

\section{Pengaplikasian Kompromi WTO atas AEC}

Dalam pemaparan tentang regionalisme telah ditentukan bahwa bentuk AEC adalah FTA dengan single market/common market. Sebagai FTA, ketentuan yang berlaku adalah article XXIV (4), (5) (b), dan 8 (b) dari GATT. Mengenai pemenuhan atas provisi tersebut tidak perlu diperdebatkan lagi karena sudah diakui oleh WTO dengan nama AFTA (ASEAN Free Trade Area). Cakupan AFTA berdasarkan database tersebut hanya terbatas pada produk berupa barang $(\text { goods })^{84}$. AFTA di dalam cetak biru AEC digunakan sebagai dasar atas komitmen yang lebih dari sekedar tarif yaitu penghilangan atas non-tarif barriers dan hal-hal lain yang mendukung arus bebas barang di dalam perdagangan intra-ASEAN ${ }^{85}$. Selain itu, disebutkan bahwa AEC memiliki agenda atas terwujudnya arus bebas barang, jasa, faktor-faktor produksi, investasi, dan kapital. Mengingat bahwa terdapat tambahan single market, dapat disimpulkan bahwa AEC tidak sama dengan AFTA karena mencakup lebih dari sekedar produk berupa benda-benda (goods),

Mengingat ketidaksamaan tersebut, apabila dasar AEC adalah AFTA dibutuhkan pemberitahuan kepada WTO atas pembentukan AEC karena saat ini FTA yang berlaku dan diakui oleh WTO adalah AFTA. Walaupun seluruh unsur yang terdapat di dalam article XXIV dari GATT terpenuhi, manifestasi AEC tidak serta merta menjadi sah. Pemenuhan syarat-syarat provisi tersebut hanya mengakibatkan pembentukan blok perdagangan yang ditermakan AEC menjadi sah secara hukum. Diperlukan elemen lain untuk menjadi sah secara penuh, yaitu legitimasi dari WTO.

\footnotetext{
${ }^{84}$ Lihat., WTO, WTO RTA Database, tersedia di http://rtais.wto.org/UI/PublicAllRTAList.aspx (diakses terakhir 27 April, 2015).

85 Lihat, AEC Blueprint, point 10.
} 
Singkat kata, kompromi WTO atas AEC menjadi dubious (ragu-ragu) atau tidak jelas (inconclusive). Hal ini disebabkan karena pembentukan AEC yang komitmennya melebihi AFTA tidak terdaftar di dalam database WTO. Sehingga dapat disimpulkan bahwa pembahasan belum dilaporkan (diberitahukan) kepada WTO, terlepas dari apakah pengakuan/recognition WTO mutlak diperlukan karena sudut pandang dalam penelitian ini hanya mengacu pada GATT dan apa yang dicari oleh WTO agar Indonesia tidak dibawa ke DSB WTO.

\section{Penutup}

Seluruh anggota negara ASEAN merupakan negara partisipan dalam GATT/WTO karena keterikatannya akibat dari 'single undertaking' untuk menjadi anggota WTO, dan sebagai anggota harus tunduk pada prinsip-prinsip yang terkandung di dalam perjanjian multilateral yang bernama GATT. Salah satu prinsipnya adalah kewajiban umum atas Most Favored Nation yang esensinya, segala perlakuan yang menguntungkan (misalnya tarif) negara anggota WTO lain berlaku juga untuk seluruh negara partisipan lainnya.

Saat ini banyak terbentuk blok-blok perdagangan regional salah satunya oleh ASEAN yang disebut dengan AEC. Berdasarkan kewajiban umum, pengaturan blok-blok perdagangan akan melanggar prinsip non-diskriminasi karena keuntungan hanya didapatkan bagi anggota dalam perjanjian regional terkait, mengingat bahwa dengan berlakunya AEC, tarif yang diberlakukan internal hampir 0\%. Namun, secara faktual tampak bahwa WTO memberikan kompromi atas regionalisme karena Uni Eropa sebagai model AEC diperbolehkan. Tetapi, terdapat perbedaan dimana European Union berbentuk customs union dan AEC menganut formasi Free-Trade Area (FTA) dengan common market. Kompromi tersebut adalah hasil dari tidak tercapainya konsensus pada negosiasi reformasi perdagangan yang dilangsungkan oleh WTO serta pengaruh WTO dalam perjanjian perdagangan regional.

Dari segi hukum, kompromi tersebut semakin dipertegas pada article XXIV dari GATT yang mensyaratkan bahwa pembentukan blok perdagangan harus 
memenuhi hal-hal sebagai berikut: (1) melengkapi perdagangan dunia yang global dan bukan menjadi ancaman; (2) mendukung perdagangan sesama anggota dalam perjanjian tersebut dan tidak menimbulkan hambatan bagi negara di luar kelompok terkait; dan (3) berkaitan dengan memajukan perdagangan intraregional, menghilangkan segala bea dan regulasi-regulasi perdagangan sehubungan dengan seluruh perdagangan secara substansial yang berlaku bagi setiap negara partisipan. Atas kasus AEC, tidak dapat ditentukan secara jelas karena meskipun memenuhi segala syarat yang terdapat di dalam article XXIV dari GATT sehingga terpenuhi secara hukum, namun ia tidak dapat mendapatkan legitimasi yang dibutuhkan karena belum terdapat di dalam database WTO yang menunjukan bahwa AEC belum dibahas di WTO, terlepas dari apakah recognition WTO mutlak diperlukan.

\section{Daftar Pustaka}

\section{Jurnal}

Alberta Fabbricotti, The Paradox Of Multilateralizing Regionalism Through Flexibility, 103 Am. Soc'y Int'l L. Proc., (2009).

Anonymous, WTO Basics, The China Bus. Rev. (2000).

C. O'Neal Taylor, Regionalism: The Second-Best Option?, 28 St. Louis U. Pub. L. Rev. (2008-2009).

Chris Brummer, The Ties That Bind? Regionalism, Commercial Treaties, And The Future Of Global Economic Integration, 60 Vand. L. Rev. (2007).

Christoph T. Feddersen, Focusing On Substantive Law In International Economic Relations: The Public Morals Of GATT's Article XX(a) And "Conventional” Rules Of Interpretation, 7 Minn. J. Global Trade (1998).

D. Mansfield Edward and V. Milner Helen, The New Wave of Regionalism, 53.3 Int'l Org. (1999).

Donald McRae, MFN In The GATT And The WTO, 7 Asian J. WTO \& Int'l Health L. \& Pol'y. (2012).

Fujian Li and Jingsha Deng, Varieties of Regionalism: Comparison Of Europe And Southeast Asia, 10 Asian Soc. Sci.,(2014)

Fred Trost, Reconciling Regional Trade Agreements With The Most Favoured Nation Principle In WTO-GATT, 5 Macquarie J. Bus. L. (2008).

Horagaio A. Grigera Naon, Sovereignty And Regionalism, 27 Law \& Pol'l Int'l Bus. (1995-1996). 
Michael Ewing-Chow, ASEAN Integration, The Rule Of Law, And Investment Agreements, 107 Am. Soc'y Int'l L. Proc. (2013).

Michael G. Plummer, ASEAN And The Theory Of Regional Economic Integration: A Survey, 14.2 ASEAN Econ. Bulletin (1997).

Mindy Chen-Wishart, Legal Transplant And Undue Influence: Lost In Translation Or A Working Misunderstanding?, 62.1 Int. and Comp. L. Q. (2013).

Mitsuo Matsushita, Regionalism And The Disciplines Of The WTO: Analysis of Some Legal Aspects Under Article XXIV Of The GATT, 13 Asia Pac. L. Rev. (2005).

Myrna S. Austria, Moving Towards An ASEAN Economic Community, 29 East Asia , pp. (2012).

Nguyen Anh Thu and Nguyen Thi Mai Anh, ASEAN and EU Economic Integration: A Comparative Analysis, ICIRD (International Conference on International Relations and Development), (2014).

Nopadol Rompho, et. al., Strategy Execution By Thai Large Companies for ASEAN Economic Community, 9.5 Int'l J. of Business And Management (2014).

Peter J. Llyod, What Is A Single Market? An Application To The Case of ASEAN, 22.3 ASEAN Economic Bulletin, pp. 252 (2005)

Salman Bal, International Free Trade Agreements And Human Rights: Reinterpreting Article XX Of The GATT, 10 Minn. J. Global Trade, (2001).

Sayantan Gupta, Changing Faces of International Trade: Multilaterism To Regionalism, 3 J. Int'l Com. L. \& Tech. (2008).

Stephen Joseph Powell And Trisha Low, Is The WTO Quietly Fading Away?, The New Regionalism And Global Trade Rules, 9 Geo. J. L. \& Pub. Pol'y, (2011).

Sungjoon Cho, Breaking The Barrier Between Regionalism And Multilateralism: A New Perspective On Trade Regionalism, 42 Harv. Int'l L. J. (2001).

Taufiqurrahman, Paradigm of Universalistic Particularism To Reform The Indonesia Economic Law In The Framework Of Establishing The 2015 ASEAN Economic Community, 4 Juridical Trib. (2014).

Tom Ginsburg, Eastphalia And Asian Regionalism, 44 U.C. Davis L. Rev., pp. 870 (2010-2011)

Warren H. Maruyama, Preferential Trade Arrangements And The Erosion of The WTO'S MFN Principle, 46 Stan. J. Int'l L., pp. 181 (2010)

Yengkong Nganjoh-Hodu, Relationship Of GATT Article XX Exceptions To Other WTO Agreements, 80 Nordic J. Int'l L. (2011).

\section{Pustaka Yang Tidak Dipublikasikan}

Johannes Gunawan, Metodologi Penelitian Hukum S3, Universitas Katolik Parahyangan, (2013).

\section{Web}

KBBI Daring, Kamus Besar Bahasa Indonesia (KBBI), versi online / daring, available at http://kbbi.web.id. 
Kiki Verico, Can ASEAN Achieve Economic Community?, Jakarta Post, http://www.e-ir.info/2012/10/07/asean-and-the-european-union-lessons-inintegration/

Siam Premier, ASEAN Economic Community And The European Union's Experience, Siam Premier International Law Office Limited, tersedia di http://siampremier.com/asean-economic-community-and-the-europeanunions-experience/

WTO, Understanding the WTO: Basics - Principles Of The Trading System, World Trade Organization, tersedia di https://www.wto.org/english/thewto_e/whatis_e/tif_e/fact2_e.htm

WTO, Understanding The WTO, Regionalism: Friends Or Rivals?, Cross-Cutting And New Issues, available at https://www.wto.org/english/thewto_e/whatis_e/tif_e/bey1_e.htm

WTO, WTO RTA Database, available at http://rtais.wto.org/UI/PublicAllRTAList.aspx

\section{Sumber Hukum}

ASEAN, ASEAN Economic Community Blueprint, tersedia di http://www.asean.org/archive/5187-10.pdf

ASEAN, ASEAN Trade In Goods Agreement, tersedia di

http://www.asean.org/images/2012/Economic/AFTA/annex/ASEAN\%20Tra de\%20in\%20Goods\%20Agreement,\%20Chaam,\%20Thailand,\%2026\%20February\%202009.pdf

GATT 1994, tersedia di https://www.wto.org/english/docs_e/legal_e/gatt47_e.pdf

WTO, WTO Analytical Index: Guide To WTO Law And Practice - General Agreement On Tariffs And Trade 1994, World Trade Organization, tersedia di https://www.wto.org/english/res_e/booksp_e/analytic_index_e/gatt1994_05_ e.htm\#article11

WTO, Dispute Settlement: DS371 - Thailand - Customs And Fiscal Measures On Cigarettes From The Philippines, available at https://www.wto.org/english/tratop_e/dispu_e/cases_e/ds371_e.htm

WTO, Dispute Settlement: DS135 - European Communities - Measures Affecting Asbestos And Products Containing Asbestos, available at https://www.wto.org/english/tratop_e/dispu_e/cases_e/ds135_e.htm WTP, Dispute Settlement: DS34 - Turkey - Restrictions on Imports of Tekstile and Clothing Product, tersedia di https://www.wto.org/english/tratop_e/dispu_e/cases_e/ds34_e.htm 